\title{
Do males and females respond differently to ocean acidification? An experimental study with the sea urchin Paracentrotus lividus
}

\author{
Tihana Marčeta $^{1,2} \cdot$ Valerio Matozzo $^{1} \cdot$ Silvia Alban $^{1} \cdot$ Denis Badocco $^{3} \cdot$ Paolo Pastore $^{3} \cdot$ Maria Gabriella Marin $^{1}$ (D)
}

Received: 26 February 2020 / Accepted: 6 July 2020 / Published online: 10 July 2020

(C) The Author(s) 2020

\begin{abstract}
Seawater $\mathrm{pH}$ lowering, known as ocean acidification, is considered among the major threats to marine environment. In this study, post-spawning adults of the sea urchin Paracentrotus lividus were maintained at three $\mathrm{pH}$ values $(8.0,7.7,7.4)$ for 60 days. Physiological, biochemical, cellular, behavioural and reproductive responses were evaluated in males and females. Significant differences between sexes were observed, with higher ammonia excretion and lower catalase activity in males. Respiration rate (after 21 days), catalase activity in gonads and total coelomocyte count showed the same increasing trend in males and females under low $\mathrm{pH}$. Ammonia excretion, gonadosomatic index and lysozyme activity exhibited opposite responses to low $\mathrm{pH}$, with an increasing trend in males and decreasing in females. Results demonstrated that exposure to low $\mathrm{pH}$ could result in different response strategies of male and female sea urchins at a physiological, biochemical and immunological level. Reduced female gonadosomatic index under low $\mathrm{pH}$ suggested decreased energy investment in reproduction.
\end{abstract}

Keywords Seaurchins $\cdot$ Ocean acidification $\cdot$ Sex $\cdot$ Biomarkers $\cdot$ Physiological parameters $\cdot$ Gonadosomatic index $\cdot$ Righting time

\section{Introduction}

Ocean acidification $(\mathrm{OA})$ is a phenomenon of lowering seawater $\mathrm{pH}$, due to the dissolution of rising atmospheric $\mathrm{CO}_{2}$. Alterations of atmospheric gas composition observed during the last two centuries are mainly originated from anthropogenic activities, first from all fossil fuels' combustion. Since preindustrial time, ocean surface $\mathrm{pH}$ has decreased by approximately 0.1 units (IPCC 2013). The present average $\mathrm{pH}$ value for shallow and surface seawaters is 8.1, and predicted global

Responsible Editor: Lotfi Aleya

Electronic supplementary material The online version of this article (https://doi.org/10.1007/s11356-020-10040-7) contains supplementary material, which is available to authorized users.

Maria Gabriella Marin

mgmar@bio.unipd.it

1 Department of Biology, University of Padova, via Ugo Bassi 58/B, 35131 Padova, Italy

2 Present address: Institute of Marine Sciences (ISMAR), CNR, Venezia, Italy

3 Department of Chemical Sciences, University of Padova, Via Marzolo 1, 35131 Padova, Italy surface $\mathrm{pH}$ reduction is of $0.06-0.32$ units by the year 2100 and 0.7 units by 2300 (Hartin et al. 2016; IPCC 2019).

Responses to OA represent a species-specific phenomenon, and the effects detected in laboratory experiments are dependent on geographic area and life-history stages of the studied species (Hall-Spencer et al. 2015), as well as on the duration of the experimental exposure (Suckling et al. 2015). There are evidence that OA can differentially affect physiology, reproduction, biochemistry and survival of marine invertebrates (McClellanGreen et al. 2007; Ellis et al. 2014; Lane et al. 2015). When exposed to OA, organisms may change their resource energy allocation and due to higher production cost of eggs compared to sperm, females could be deemed more vulnerable to this stressor. Notwithstanding, Ellis et al. (2017) reported in their review that only $3.77 \%$ of 511 OA studies published between January 2008 and May 2016 tested gender-related responses in fish, crustaceans, echinoderms and molluscs. When tested, sex significantly influenced the response to OA, suggesting that sex has to be considered in order to correctly evaluate the impact at the population level (Ellis et al. 2017).

Among aquatic species, echinoderms are considered as model organisms to assess the effects of changing environmental conditions. Echinoderms include exclusively marine species, such as sea urchins, which build calcareous skeleton in both larval and adult phase. Skeletal rods in larvae and test, teeth and spines in 
adults are formed from magnesium calcite that is one of the most soluble forms of calcium carbonate (Morse et al. 2006). In longterm experimental exposures to OA, sea urchins revealed mostly negative but sub-lethal effects, with diminished calcification as principal impairment in both adult and larval stages. Although sea urchin species inhabiting low $\mathrm{pH}$ environments such as upwelling regions, intertidal pools, and $\mathrm{CO}_{2}$ vents exhibited great potential to adapt to OA, in about 20 species of echinoplutei from several world regions and habitats, reduction in growth and increased alteration of body morphology were observed (Byrne and Hernández 2020). Long-lasting experiments can allow us to inspect organisms' capability to acclimate to low $\mathrm{pH}$ and to produce more relevant data for predicting long-term consequences of OA. It was demonstrated that short-term exposures to low $\mathrm{pH}$ values could lead to hypercapnic conditions in sea urchin coelomic fluid (Miles et al. 2007; Spicer et al. 2011; Dupont and Thorndyke 2012; Spicer and Widdicombe 2012; Stumpp et al. 2012; Holtmann et al. 2013; Kurihara et al. 2013). This effect could represent a "shock" response (Byrne 2012; Queirós et al. 2015) possibly related to both the absence of respiratory pigments and low capability of sea urchins to regulate ions. Generally, in most species, with few exceptions (Kurihara et al. 2013), the acid-base balance is recovered in some days or weeks (Calosi et al. 2013; Dupont and Thorndyke 2012; Stumpp et al. 2012; Holtman et al. 2013; Moulin et al. 2014). Experiments on Paracentrotus lividus (from 6 days to 2 months long) showed an increased coelomic fluid buffer capacity under low $\mathrm{pH}$. However, in this species, coelomic fluid $\mathrm{pH}$ seems to be only partially compensated at extreme $\mathrm{pH}$ condition $(7.4 \mathrm{pH})$. This compensation of the coelomic fluid $\mathrm{pH}$ in $P$. lividus was not dependent on skeleton dissolution, indeed skeletal mechanical properties were not affected at $7.7 \mathrm{pH}$ (Catarino et al. 2012; Collard et al. 2013, 2014, 2016; Cohen-Rengifo et al. 2019). The acid-base regulation capability allows sea urchins to maintain appropriate extracellular and intracellular $\mathrm{pH}$ conditions, but the processes involved in this regulation are energy-consuming and lead to increased oxygen uptake. Therefore, other processes such as growth, reproduction and behaviour could be compromised if energy acquisition is not increased (Dupont et al. 2013).

It is supposed that increased levels of $\mathrm{CO}_{2}$ cause oxidative stress directly by increasing the production of ROS and/or indirectly by lowering internal $\mathrm{pH}$, which may induce the release of chelated transition metals such as $\mathrm{Fe}^{2+}$ from intracellular compartments and enhance the Fenton reaction (Tomanek et al. 2011). Induction of oxidative stress by low $\mathrm{pH}$ has been scarcely investigated in marine echinoderms (Migliaccio et al. 2019), but it was evaluated and detected in other taxa, such as marine bivalves (Tomanek et al. 2011; Matozzo et al. 2013; Benedetti et al. 2016; Velez et al. 2016; Freitas et al. 2017a; Nardi et al. 2017; Sui et al. 2017; Huang et al. 2018; Munari et al. 2018), crustaceans (Priya et al. 2017; Rato et al. 2017; Glippa et al. 2018), polychaetes (Freitas et al. 2017b), gastropods (Cardoso et al. 2017), corals (Soriano-
Santiago et al. 2013) and fish larvae (Pimentel et al. 2015). In all these studies, the exposure to OA conditions lasted from at least $72 \mathrm{~h}$ to a maximum of 1 month. For the sea urchin $P$. lividus, seasonal changes in biomarker responses were observed in specimens from the Gulf of Annaba (Algeria), with an increase in antioxidant enzymes' activity during the reproductive period (spring), suggesting that for this species natural physiological cycle as well as biotic and abiotic factors could influence oxidative stress responses (Amri et al. 2017).

As demonstrated in Lytechinus variegatus, Echinometra lucunter and Strongylocentrotus droebachiensis, ocean acidification affects adult sea urchin immune system after a short-term exposure (from $24 \mathrm{~h}$ to 7 days). Alterations of immunological parameters seem to be mainly linked to $\mathrm{pH}$ decrease in coelomic liquid and appeared reversible when natural values were reestablished (Dupont and Thorndyke 2012; Leite Figueiredo et al. 2016).

Effects of OA on sea urchin fecundity was evaluated mainly by measurement of gonadic mass production (Siikavuopio et al. 2007; Stumpp et al. 2012; Kurihara et al. 2013; Taylor et al. 2014; Uthicke et al. 2014; Mos et al. 2016; Dworjanyn and Byrne 2018), as well as by determination of egg number and size, gamete performance or RNA/DNA ratio in gonads (Catarino et al. 2012; Cohen-Rengifo et al. 2013; Dupont et al. 2013; Uthicke et al. 2013; Suckling et al. 2014; Graham et al. 2015; Campbell et al. 2016; Karelitz et al. 2020).

In the present study, adults of the sea urchin P. lividus were used as model organism. This species is widely distributed in the Mediterranean and in the north-eastern Atlantic (Boudouresque and Verlaque 2013), where it plays a dominant role as a grazer and acts as a keystone species in controlling dynamic, structure and composition of infralittoral macroalgal assemblages (Hereu 2006; Privitera et al. 2008; Boudouresque and Verlaque 2013). During a 60-day experiment, post-spawning adults of $P$. lividus were exposed to control $\mathrm{pH}(8.0)$ and to two reduced $\mathrm{pH}$ values, 7.7 and 7.4, according to projections for shallow and surface seawaters by 2100 and 2300, respectively (Hartin et al. 2016; IPCC 2019). A number of physiological, biochemical, cellular, behavioural and reproductive responses were investigated in both males and females. The hypotheses we tested were as follows: (i) $\mathrm{OA}$ affects the biological responses measured in P. lividus; (ii) males and females respond differently to OA.

\section{Materials and methods}

\section{Specimen collection}

About 200 adult specimens of $P$. lividus, with a live weight of $36.7 \pm 11.4 \mathrm{~g}$ and a test diameter of $4.5 \pm 0.5 \mathrm{~cm}$, were collected by SCUBA divers at approximately $5 \mathrm{~m}$ depth in the southern basin of the Venice Lagoon (NW Adriatic Sea, Italy) 
between February and March 2017. The sampling area is close to the southern inlet of the lagoon where pollution levels are generally low (Parolini et al. 2010; Parolini et al. 2012; Cassin et al. 2018; Zonta et al. 2018). In the laboratory, animals were acclimated in flow-through aquaria for 2 weeks at least, at $18 \pm 0.5^{\circ} \mathrm{C}$ temperature and $34 \pm 1$ salinity, and fed with Ulva sp. In order to recognize male and female sea urchins and to obtain individuals in the same very early stage of gametogenesis, all specimens were induced to spawn, by injecting $0.5 \mathrm{ml}$ of $0.5 \mathrm{M} \mathrm{KCl}$ solution into the coelom, through the peristome membrane (Gago and Luís 2011). After that, males and females were maintained in separate aquaria and allowed to recover for a week in the previously reported conditions. Prior to exposure, the sea urchins were acclimatized to the experimental conditions by gradually reducing the natural $\mathrm{pH}$ values by about -0.3 or -0.6 units (approximately 0.1 reduction per day).

\section{Experimental sea urchin culture system}

Post-spawning adults of $P$. lividus were kept under three $\mathrm{pH}$ values: 8.0, 7.7 and 7.4. Each experimental condition was assessed in triplicate 601 tanks, each containing at least six males and nine females separated by a plastic grid. Tanks were supplied with filtered seawater $(5 \mu \mathrm{m})$ at a flow rate of $300 \mathrm{ml} \mathrm{min}{ }^{-1}$ and were equipped with an aerator. In each individual low $\mathrm{pH}$ (7.7 and 7.4) tank, the $\mathrm{pH}$ value was maintained by bubbling $\mathrm{CO}_{2}$ using an electronic control system (Aquarium Controller Evolution, mod. ACQ110, Aquatronica, Italy) connected to a $\mathrm{pH}$ electrode (ACQ310N$\mathrm{pH}$ by Aquatronica, Italy). To verify and adjust $\mathrm{pH}$ electrode measurements, in each experimental tank $\mathrm{pH}$ value was checked twice a day at least using a benchtop pH-meter Basic 20+ (Crison, Spain) calibrated daily with Crison buffer solutions.

In order to promote the gonadal maturation, sea urchins were fed ad libitum with fresh Ulva sp., and maintained at $18{ }^{\circ} \mathrm{C}$ temperature (Grosjean et al. 1998), and $9 \mathrm{~h}$ light: $15 \mathrm{~h}$ dark photoperiod (Spirlet et al. 2000). Salinity values were in the same range measured during the acclimation period. Throughout the experiment, no spontaneous spawning event was observed.

At each experimental condition, sea urchins were randomly sampled within the tanks and physiological effects were evaluated after 7, 14, 21 and 40 days through measurements of respiration rate, ammonia production rate and assimilation rate. Due to some technical inconveniences, data were not collected at day 40 for ammonia production and at days 21 and 40 for assimilation. For each parameter measured, four males and four females per experimental condition were used. After 40 days, righting time (see below for details) was also measured on six males and six females per experimental condition. Physiological and behavioural measurements were performed at the same $\mathrm{pH}$, temperature and salinity used during exposure. After 60 days of exposure to differing $\mathrm{pH}$ values, six males and six females were used to evaluate gonadosomatic index, superoxide dismutase (SOD) and catalase (CAT) activity in gonads and digestive tract, coelomocyte number and volume (TCC and CV respectively) and lysozyme activity in coelomic fluid and coelomocytes.

\section{Seawater chemistry}

On days 30,50 and 60, seawater samples from each experimental condition were collected into $250 \mathrm{ml}$ polypropylene bottles. In order to halt the biological activity, samples were immediately poisoned with $100 \mu \mathrm{l}$ of saturated mercuric chloride solution $\left(\mathrm{HgCl}_{2}\right)$ and were stored at $4{ }^{\circ} \mathrm{C}$ in the dark until analysis.

Total alkalinity (TA) was determined via potentiometric titration using an automatic titrator (836 Titrando, Metrohom). Each seawater sample was thermostated at $25{ }^{\circ} \mathrm{C}$ (HAAKE C25P Phoenix II, ENCO) before titration. A synthetic alkalinity standard was prepared following the method of Dickson et al. (2003) and used as a reference. The estimate of the extended uncertainty interval was $4.9 \%$ with respect to the TA value of the standard. All TA values obtained with the synthetic alkalinity standard in the analysis of the real samples were compliant. The $4.3 \%$ of the titrations of the seawater samples were repeated more than two times to meet the relative precision specifications of $2 \%$ obtained in the validation of the TA standard.

The dissolved inorganic carbon (DIC) content, carbonate concentration values and $\mathrm{CO}_{2}$ partial pressure $\left(\mathrm{pCO}_{2}\right)$ in seawater were computed at the sampling temperature, salinity and $\mathrm{pH}_{\mathrm{T}}$ using the $\mathrm{TA}$ values. All thermodynamic equilibrium constants were computed according to Millero (1979), Millero (1995) and Millero et al. (2006). The solubility values of calcite and aragonite were obtained from Mucci (1983) and from Ingle (1975). The saturation states of calcite $\left(\Omega_{\mathrm{ca}}\right)$ and aragonite $\left(\Omega_{\text {ar }}\right)$ were computed based on the solubility products reported in Millero (1979). Results are reported in Table 1.

\section{Respiration rate}

Since feeding increases the buffer capacity and non-fed individuals can undergo severe metabolic acidosis (Stumpp et al. 2012; Collard et al. 2013), sea urchins were not fasted before respiration measurements to reproduce the environmental conditions more faithfully and to avoid additional stress. To measure oxygen consumption, individual sea urchins were placed in 0.81 plexiglas respirometry chambers provided with a magnetic stirrer bar placed under a perforated plate. Chambers were filled with air-saturated $0.45 \mu \mathrm{m}$-filtered seawater at each $\mathrm{pH}$ studied and placed on the multi-position 
Table 1 Seawater carbonate chemistry variables (mean values $\pm \mathrm{SD} ; n=9$ ) recorded during the experiment

\begin{tabular}{lllllrl}
\hline Tanks & $\mathrm{pH}_{\mathrm{T}}$ & $\mathrm{DIC}\left(\mu \mathrm{mol} \mathrm{kg}{ }^{-1}\right)$ & $\mathrm{TA}\left(\mu \mathrm{mol} \mathrm{kg}{ }^{-1}\right)$ & $\mathrm{pCO}_{2}(\mu \mathrm{Atm})$ & $\Omega_{\mathrm{Ca}}$ & $\Omega_{\mathrm{Ar}}$ \\
\hline $8.0 \mathrm{pH}$ & $8.02 \pm 0.03$ & $2564.97 \pm 110.81$ & $2772.47 \pm 120.47$ & $544.02 \pm 59.42$ & $5.65 \pm 0.12$ \\
$7.7 \mathrm{pH}$ & $7.69 \pm 0.02$ & $2703.25 \pm 25.32$ & $2780.86 \pm 27.43$ & $1263.29 \pm 41.99$ & $2.95 \pm 0.17$ & $1.92 \pm 0.11$ \\
$7.4 \mathrm{pH}$ & $7.38 \pm 0.02$ & $2783 \pm 43.71$ & $2757.13 \pm 42.10$ & $3643.17 \pm 88.35$ & $1.47 \pm 0.05$ & $0.95 \pm 0.03$ \\
\hline
\end{tabular}

$T A$, total alkalinity; $D I C$, total dissolved inorganic carbon; $\mathrm{pCO}_{2}, \mathrm{CO}_{2}$ partial pressure; $\Omega c a$, calcite saturation state; $\Omega a r$, aragonite saturation state

magnetic stirrer. During measurements, the chambers were kept at $18{ }^{\circ} \mathrm{C}$ using a thermostatic bath. For each batch, a chamber without sea urchin was used as a control. Oxygen concentration was measured after $0,30,60$ and 90 min using an optical oxygen meter (fibre-optic oxygen meter-Piccolo2, Pyro Science GmbH, Aachen, Germany). Oxygen saturation never fell below 70\% during the trial. Oxygen uptake $\left(\mu \mathrm{molO} \mathrm{h}^{-1} \mathrm{~g}^{-1}\right.$ ) was calculated by multiplying the slope of the oxygen depletion curve by the volume of seawater inside the chamber and dividing by the live sea urchin weight. The volume of water was determined by subtracting the volume of each sea urchin from the total volume in the chamber.

\section{Ammonia excretion}

Ammonia excretion ( $\mu$ molN-NH $\mathrm{h}_{3} \mathrm{~g}^{-1}$ ) was measured in water samples collected from each respirometry chamber after $90 \mathrm{~min}$. Ammonia was determined spectrophotometrically according to the method of Solorzano (1969). Ammonia excretion was calculated from the difference in ammonia concentration between the chambers with and without animals and referred to sea urchin live weight.

\section{Assimilation efficiency}

To measure assimilation efficiency, sea urchins were placed individually in 2.5-1 beakers filled with filtered seawater $(0.45 \mu \mathrm{m})$ for $24 \mathrm{~h}$ and during this period they were not fed. Faeces from each beaker were drawn off, filtered on pre-ashed and weighed glass fibre filters (Whatman GFC), and rinsed with distilled water to remove the salt. Filters were then dried in an oven at $60{ }^{\circ} \mathrm{C}$, weighed after $24 \mathrm{~h}$, ashed in a muffle furnace at $450^{\circ} \mathrm{C}$ for $4 \mathrm{~h}$ and re-weighed (Conover 1966; Reid et al. 2010). Weight determinations were performed using a Mettler Toledo, XS105 Dual Range analytical balance ( $0.01 \mathrm{mg}$ readability). The same procedure was applied in triplicate on diet samples. In faeces and algae, organic content (OC) was calculated as ash-free dry weight obtained as the difference between dry and ash weight. Absorption efficiency (AE) was determined according to Conover (1966): $\mathrm{AE}=[($ DietOC - FaecesOC $) /(1-$ FaecesOC $) \times$ DietOC $] \times$ 100, where DietOC and FaecesOC are the organic fractions in algae and in faeces, respectively.

\section{Superoxide dismutase and catalase activity}

Gonads and digestive tract were dissected from six males and six females and aliquots of the individual tissues were placed in tubes and immediately frozen in liquid nitrogen and stored at $-80^{\circ} \mathrm{C}$ until analysis. The gonads and digestive tract were thawed on ice and homogenized (1:4, w:v) in $0.1 \mathrm{M}$ Tris- $\mathrm{HCl}$ buffer ( $\mathrm{pH} 7.5$ ) containing $0.15 \mathrm{M} \mathrm{KCl}, 0.5 \mathrm{M}$ sucrose, $1 \mathrm{mM}$ EDTA and $1 \mathrm{mM}$ dithiothreitol (DTT, Sigma). Homogenates were centrifuged at $12,000 \mathrm{~g}$ for $45 \mathrm{~min}$ at $4{ }^{\circ} \mathrm{C}$ and supernatants (SN) were collected to measure antioxidant enzyme activities. To this aim, widely validated methods in sea urchins were used in this study (Zuo et al. 2018; Klein et al. 2019; Zapata-Vivenes and Aparicio 2019).

Total SOD activity was measured in SN of gonads and digestive tract with the xanthine oxidase/cytochrome $\mathrm{C}$ method in accordance with Crapo et al. (1978). The cytochrome C reduction by superoxide anion generated by xanthine oxidase/ hypoxanthine reaction was detected using a Beckman Coulter (DUß Series 730) spectrophotometer at $550 \mathrm{~nm}$ at room temperature $\left(20^{\circ} \mathrm{C}\right)$. Enzyme activity was expressed as $\mathrm{U} \mathrm{mg}^{-1}$ of protein, 1 unit of SOD is defined as the amount of sample producing 50\% inhibition of cytochrome $\mathrm{C}$ reduction in the assay conditions. The reaction mixture contained $46.5 \mu \mathrm{M}$ $\mathrm{KH}_{2} \mathrm{PO}_{4} / \mathrm{K}_{2} \mathrm{HPO}_{4}$ (pH 8.6), $0.1 \mathrm{mM}$ EDTA, $195 \mu \mathrm{M}$ hypoxanthine, $16 \mu \mathrm{M}$ cytochrome $\mathrm{c}$ and $2.5 \mu \mathrm{U}$ xanthine oxidase.

CAT activity was measured in tissue SN following the method described in Aebi (1984). Decreases in absorbance of a $50-\mathrm{mM} \mathrm{H}_{2} \mathrm{O}_{2}$ solution $\left(\varepsilon=-0.0436 \mathrm{mM}^{-1} \mathrm{~cm}^{-1}\right)$ in $50 \mathrm{mM}$ phosphate buffer $(\mathrm{pH} 7.8)$ and $10 \mu \mathrm{l}$ of tissue $\mathrm{SN}$ were continuously recorded at $240 \mathrm{~nm}$ and at 10 -s intervals for $1 \mathrm{~min}$. The results were expressed as $\mathrm{U} \mathrm{mg}^{-1}$ of protein, 1 unit of CAT being defined as the amount of enzyme that catalyses the dismutation of $1 \mu \mathrm{mol}$ of $\mathrm{H}_{2} \mathrm{O}_{2} \mathrm{~min}^{-1}$.

For both SOD and CAT assays, SN protein concentrations were quantified in accordance with Bradford (1976).

\section{Coelomic fluid collection}

Two millitres of coelomic fluid were collected from the peristomial membrane of each animal, with a plastic syringe, and stored in ice. Coelomic fluid $(1 \mathrm{ml})$ was used to determine the total coelomocyte count (TCC) and coelomocyte volume 
$(\mathrm{CV})$, while $1 \mathrm{ml}$ was used to measure both lysozyme activity and total protein concentration in coelomocyte lysate (CL) and cell-free coelomic fluid (CFC).

\section{Total coelomocyte count and coelomocyte volume}

A Coulter counter (Z2 mod., Beckman Coulter) was used to determine TCC and $\mathrm{CV}$ after adding $1 \mathrm{ml}$ of coelomic fluid to $19 \mathrm{ml}$ of $0.45 \mu \mathrm{m}$-filtered seawater. TCC results were expressed as the number of coelomocytes $\left(\times 10^{6}\right) \mathrm{ml}$ coelomic fluid $^{-1}$. The haemocyte volume was expressed in femtolitres (fl).

\section{Lysozyme activity}

Lysozyme activity was quantified in both CFC and CL, according to Santarém et al. (1994) and Fernández-Boo et al. (2018). Coelomic fluid from each sea urchin was centrifuged at $780 \mathrm{~g}$ for $10 \mathrm{~min}$. The supernatant, corresponding to CFC, was collected, whereas the coelomocytes were resuspended in distilled water and sonicated at $4{ }^{\circ} \mathrm{C}$ for $1 \mathrm{~min}$ to obtain CL. CL and CFC were frozen and stored at $-80{ }^{\circ} \mathrm{C}$ before analyses. Fifty microlitres of CL and CFC were added to $950 \mu \mathrm{l}$ of a $0.15 \%$ suspension of Micrococcus lysodeikticus (Sigma) in $66 \mathrm{mM}$ phosphate buffer, $\mathrm{pH} 6.2$; and the decrease in absorbance $\left(\Delta \mathrm{A} \mathrm{min}{ }^{-1}\right)$ was continuously recorded at $450 \mathrm{~nm}$ for $5 \mathrm{~min}$ at room temperature. Standard solutions containing 1, 2.5, 5 and $10 \mu \mathrm{g}$ lysozyme per $\mathrm{ml}$ of $66 \mathrm{mM}$ phosphate buffer, $\mathrm{pH} 6.2$, were prepared from crystalline hen egg-white lysozyme (Sigma). The average decrease in absorbance per minute was determined for each enzyme solution, and a standard curve of enzyme concentration versus $\Delta \mathrm{A}$ $\min ^{-1}$ was drawn. Results were expressed as $\mu \mathrm{g}$ lysozyme mg protein ${ }^{-1}$. CL and CFC protein concentrations were also quantified according to Bradford (1976).

\section{Righting time}

Each animal was tested three times in water from its exposure tank. At the beginning of the trial, the sea urchin was placed on its aboral surface and the time used by each animal to right itself completely was recorded. The test was carried out using a 51 plastic rectangular container with a smooth surface and large enough to avoid contact between vertical walls and the animal. After the first experimental trial, water was completely removed from the container in order to detach the sea urchin without disturbing it. Each individual was maintained in its experimental tank for $1 \mathrm{~h}$ before repeating the measurement.

\section{Gonadosomatic index}

Live sea urchins were weighed using a digital balance $( \pm$ $0.01 \mathrm{~g}$ ) and dissected to obtain the gonads. Dissected gonads were weighed and GSI was calculated as the percentage of fresh weight of gonads respect to the live weight of the animal.

\section{Statistical analysis}

For all the parameters considered, significant effects due to $\mathrm{pH}$, sex and $\mathrm{pH}^{*}$ sex interaction were assessed by linear mixed models with a tank as a random effect and followed by the Tukey post-hoc correction. The threshold for significance was set at $p<0.05$.

Lastly, a canonical correlation analysis (CCA) was performed using a data matrix made up on all biomarkers' measurements (i.e., respiration rate, SOD and CAT activity in gonads and digestive tract, total coelomocyte number and volume, lysozyme activity in $\mathrm{CL}$ and $\mathrm{CFC}$, righting time and gonadosomatic index) detected in males and females after at least 40 days of exposure. The set of variables included are $\mathrm{pH}$ and gender vs the measured physiological, cellular and biochemical parameters. All statistical analyses were performed using package R (R Core Team 2019, Austria) with the CCA package (González and Déjean 2012) and r41sqrt10 package (Finos 2020).

\section{Results}

Detailed statistical results for all biomarkers measured are shown in the Supplementary material.

\section{Physiological parameters}

No effects of the experimental conditions tested were recorded in respiration rate after 7 and 40 days of exposure (Fig. 1a, Table 2). After 14 days, this parameter was significantly affected by gender and showed higher values in males compared with females. A significant effect of $\mathrm{pH}$ was recorded after 21 days of exposure, with a significant increase in respiration rate at $7.4 \mathrm{pH}$ respect to $7.7 \mathrm{pH}$ in both males and females.

No effects of the variables considered on ammonia excretion were observed at 7 days (Table 2). As in respiration rate, a significant effect of sex was observed after 14 days, with higher values in males than in females. After 21 days, ammonia excretion $\mathrm{pH}^{*}$ sex interaction was significant. In details, a marked decrease in ammonia excretion was recorded in males kept at $7.4 \mathrm{pH}$, whereas the same was observed in females maintained at $7.7 \mathrm{pH}$ (Fig. 1b). A significant effect of interaction between $\mathrm{pH}$ and sex on assimilation efficiency was detected after 7 days of exposure (Table 2). Under low $\mathrm{pH}$ values, this parameter showed decreased values in males, while an increase was observed in females, mostly at $7.7 \mathrm{pH}$ (Fig. 1c). 


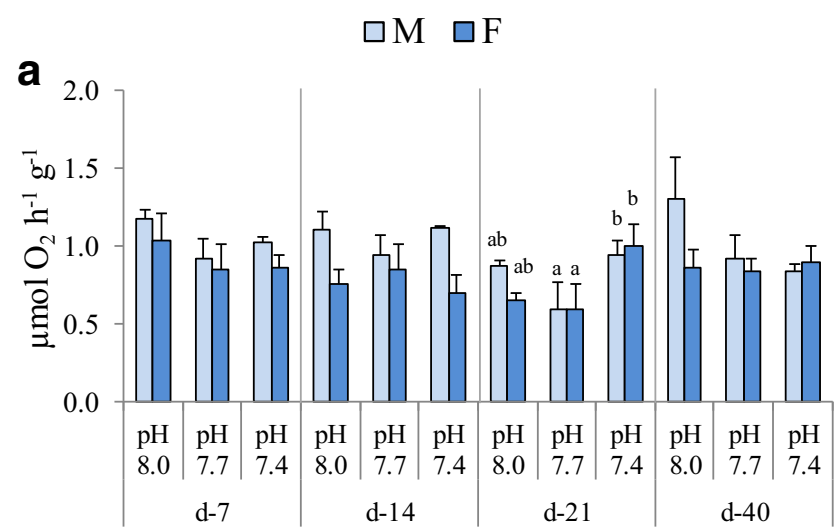

b

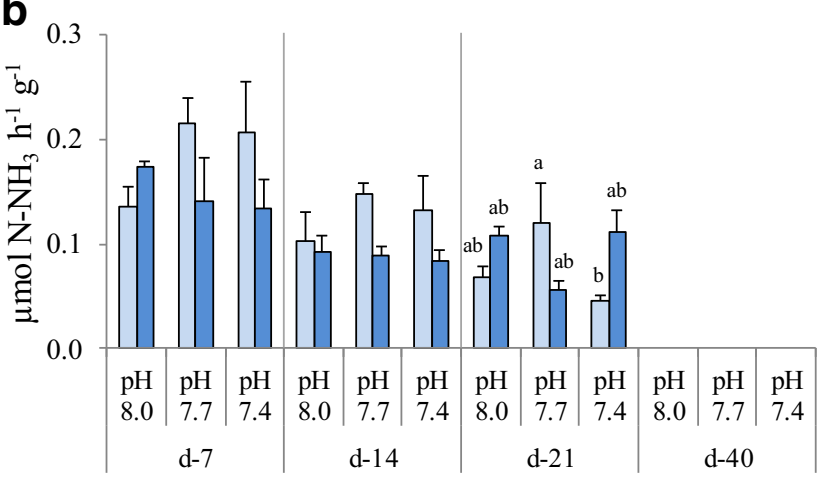

C

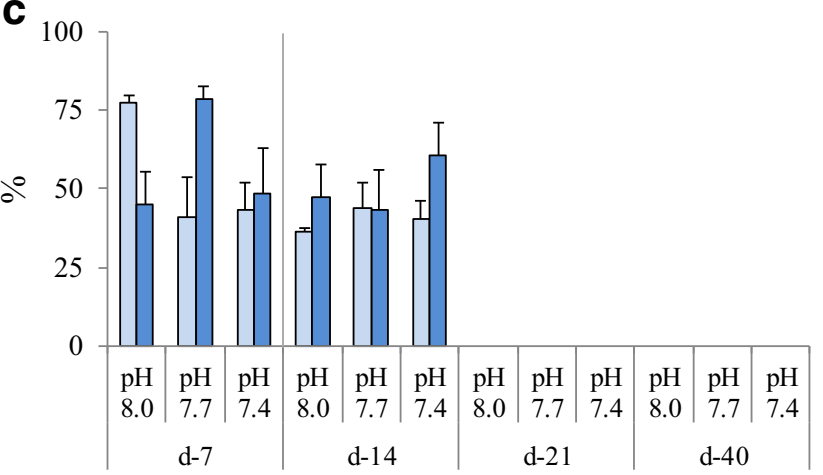

Fig. 1 Respiration rate (a), ammonia excretion (b) and assimilation efficiency (c) of $P$. lividus males (M) and females (F) after 7, 14, 21 and 40-day exposure to 8.0,7.7 and 7.4 pH. Values are the means $\pm \mathrm{SD}$ $(n=3)$. Significant differences among the various experimental conditions are presented with lower case letters $(\mathbf{a}, \mathbf{b})$. Due to some technical inconveniences, data are not available at day 40 for ammonia production and at days 21 and 40 for assimilation

\section{Antioxidant enzyme activities}

In both gonads and digestive tract, $\mathrm{pH}$, sex and their interaction did not affect significantly SOD activity (Fig. 2a, b, Table 3). Conversely, CAT activity in gonads was significantly affected by sex (Table 3 ), showing higher values in females than in males (Fig. 2c). In the digestive tract, both $\mathrm{pH}$ and sex influenced significantly CAT activity (Table 3 ). In these tissues, an increasing trend in CAT activity was observed at low $\mathrm{pH}$ with higher values in females. In particular, the activity
Table 2 Linear mixed model results for respiration rate, ammonia production and assimilation efficiency in $P$. lividus, after 7, 14, 21 and 40 days of exposure to $8.0,7.7$ and $7.4 \mathrm{pH}$. Due to some technical inconveniences, data are not available at day 40 for ammonia production and at days 21 and 40 for assimilation. Significant effects are in italics

\begin{tabular}{lllllll}
\hline & Factor & & $\mathrm{d}-7$ & $\mathrm{~d}-14$ & $\mathrm{~d}-21$ & $\mathrm{~d}-40$ \\
\hline Respiration rate & $\mathrm{pH}$ & $p$ & 0.341 & 0.892 & 0.000 & 0.182 \\
& $\mathrm{sex}$ & $p$ & 0.336 & 0.005 & 0.386 & 0.214 \\
& $\mathrm{pH}$ sex & $p$ & 0.914 & 0.256 & 0.350 & 0.268 \\
Ammonia production & $\mathrm{pH}$ & $p$ & 0.855 & 0.806 & 0.799 & \\
& $\mathrm{sex}$ & $p$ & 0.353 & 0.043 & 0.354 & \\
Assimilation efficiency & $\mathrm{pH}$ sex & $p$ & 0.303 & 0.677 & 0.001 & \\
& $\mathrm{pH}$ & $p$ & 0.322 & 0.660 & & \\
& $\mathrm{sex}$ & $p$ & 0.689 & 0.220 & & \\
& $\mathrm{pH} H^{*} \mathrm{sex}$ & $p$ & 0.008 & 0.593 & & \\
\hline
\end{tabular}

was significantly higher in females at $7.4 \mathrm{pH}$ with respect to males at 8.0 and $7.7 \mathrm{pH}$ (Fig. 2d).

\section{Coelomocyte and coelomic fluid parameters}

TCC was significantly affected by $\mathrm{pH}$ (Table 3 ). Higher TCC values were observed at $7.4 \mathrm{pH}$ in both sexes, in particular males at $7.4 \mathrm{pH}$ showed significantly higher coelomocyte number compared to females at $7.7 \mathrm{pH}$ (Fig. 3a). On the contrary, CV values were not significantly influenced by the experimental conditions tested (Fig. 3b, Table 3). In both CFC and CL, lysozyme activity was significantly affected by $\mathrm{pH}^{*}$ sex interaction (Table 3). Interestingly, lysozyme activity showed the same pattern of variation in CFC and CL (Fig. 3c, d). At $8.0 \mathrm{pH}$, females showed significantly higher CFC lysozyme activity compared to males. No $\mathrm{pH}$-induced variations in CFC lysozyme activity were observed in females, whereas in males a significant increase of the enzyme activity was observed at $7.7 \mathrm{pH}$ respect to control (Fig. 3c).

\section{Righting time and gonadosomatic index}

Although no significant effects of the experimental conditions were found (Table 3), a slight decrease in righting time was shown in females under reduced $\mathrm{pH}$, but not in males (Fig. 4a). GSI values were significantly influenced by $\mathrm{pH}^{*}$ sex interaction (Table 3). At decreasing $\mathrm{pH}$, GSI showed an opposite trend in the two sexes, slightly increasing in males and markedly decreasing in females (Fig. 4b). Females maintained at $7.4 \mathrm{pH}$ showed a significantly lower GSI compared with females from the control condition. 
Fig. 2 SOD and CAT activity in gonads $(\mathbf{a}, \mathbf{c})$ and digestive tract $(\mathbf{b}, \mathbf{d})$ of $P$. lividus males $(\mathrm{M})$ and females (F) after 60-day exposure at $8.0,7.7$ and $7.4 \mathrm{pH}$. Values are the means $\pm \mathrm{SD}(n=3)$.

Significant differences among the various experimental conditions are presented with lower case letters $(\mathbf{a}, \mathbf{b})$
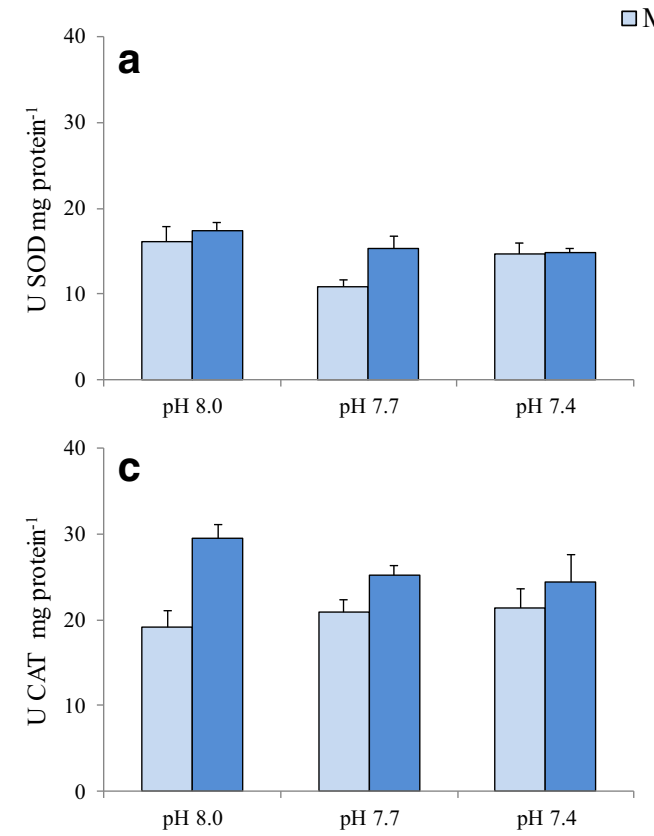
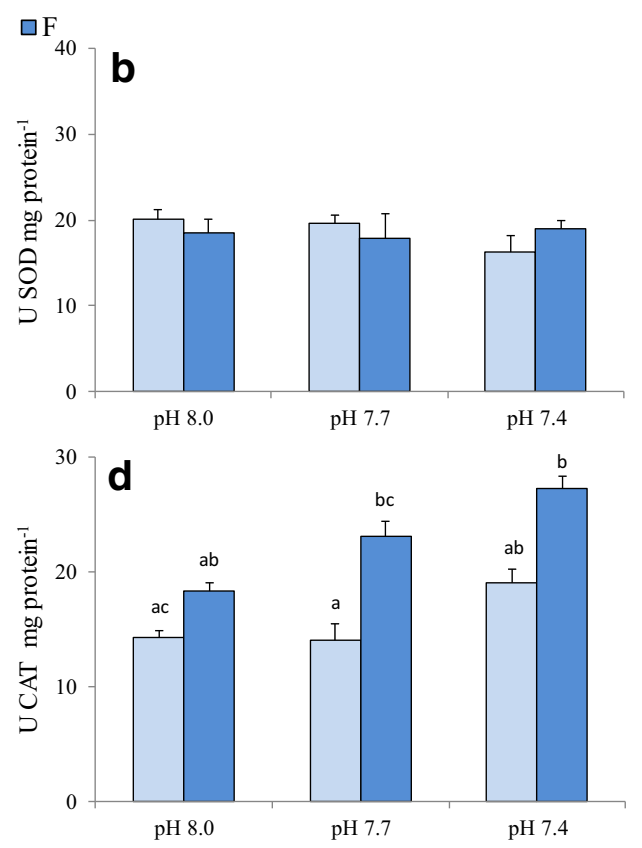

\section{Canonical correlation analysis}

The CCA performed on the whole dataset of biomarkers measured from day 40 to day 60 is shown in Fig. 5. The explained correlation is $99 \%$ for both canonical correlations. The CCA biplot reveals two clear pairs of canonical components. The first canonical component is roughly associated with the $\mathrm{pH}$ level, while the second is associated with the gender. There is a clear separation of $\mathrm{pH} 7.4$ in both males and females. In particular, control females and those at $7.7 \mathrm{pH}$ are well discriminated, while there is a less evident separation between the same $\mathrm{pH}$ conditions in males.

\section{Discussion}

The increased $\mathrm{CO}_{2}$ concentration in seawater can affect marine organisms both directly, as $\mathrm{CO}_{2}$ enters the organisms by diffusion inducing hypercapnia (i.e., $\mathrm{CO}_{2}$ accumulation in the internal fluids) and indirectly through acidosis (i.e., internal
$\mathrm{pH}$ decrease). In sea urchins, regulation of internal $\mathrm{pH}$ under seawater acidification is documented in both laboratory and natural conditions (Catarino et al. 2012; Dupont and Thorndyke 2012; Collard et al. 2013; Leite Figueiredo et al. 2016; Lewis et al. 2016; Migliaccio et al. 2019). Maintenance of acid-base homeostasis is attained by increasing bicarbonate levels in the coelomic fluid, as demonstrated in P. lividus and S. droebachiensis exposed to reduced pH (Collard et al. 2013; Stumpp et al. 2012). However, this is an energy-requiring process possibly leading to a reduction in the energy that can be allocated to other processes, such as growth and reproduction (Melzner et al. 2009; Collard et al. 2013). In this context, variations in physiological responses as a proxy for metabolic expenditure have been assessed in our study. After 21 days of exposure to reduced $\mathrm{pH}, P$. lividus respiration rate decreased at 7.7 and increased at $7.4 \mathrm{pH}$, the difference resulting significant between the two reduced $\mathrm{pH}$ conditions in both males and females. In the same species, increased respiration rate was observed by Catarino et al. (2012) after 19 days of exposure to reduced $\mathrm{pH}(7.7$ and 7.4) at a
Table 3 Linear mixed model results for superoxide dismutase (SOD) and catalase (CAT) activities in gonads and digestive tract, total coelomocyte count (TCC) and coelomocyte volume (CV), lysozyme activity (Lyso) in cell-free coelomic fluid (CFC) and coelomocytes (CL), righting time (RT) and gonadosomatic index (GSI) in P. lividus. Significant effects are in italics

\begin{tabular}{|c|c|c|c|c|c|c|c|c|c|c|c|}
\hline \multirow[b]{2}{*}{ Factor } & & \multicolumn{2}{|l|}{ SOD } & \multicolumn{2}{|l|}{ CAT } & \multirow[b]{2}{*}{ TCC } & \multirow[b]{2}{*}{$\mathrm{CV}$} & \multicolumn{2}{|l|}{ Lyso } & \multirow[b]{2}{*}{ RT } & \multirow[b]{2}{*}{ GSI } \\
\hline & & Gonad & Dig. tract & Gonad & Dig. tract & & & $\mathrm{CFC}$ & $\mathrm{CL}$ & & \\
\hline $\mathrm{pH}$ & $p$ & 0.159 & 0.637 & 0.887 & 0.011 & 0.011 & 0.801 & 0.110 & 0.511 & 0.256 & 0.429 \\
\hline $\operatorname{sex}$ & $p$ & 0.198 & 0.902 & 0.017 & 0.00 & 0.381 & 0.465 & 0.459 & 0.884 & 0.375 & 0.232 \\
\hline $\mathrm{pH}^{*} \mathrm{sex}$ & $p$ & 0.534 & 0.363 & 0.440 & 0.506 & 0.239 & 0.588 & 0.002 & 0.034 & 0.361 & 0.002 \\
\hline
\end{tabular}


Fig. 3 Total coelomocyte count, TCC (a), coelomocyte volume, $\mathrm{CV}$ (b), lysozyme activity in CFC (c) and in CL (d) in P. lividus males $(\mathrm{M})$ and females $(\mathrm{F})$ after 60-day exposure to 8.0, 7.7 and $7.4 \mathrm{pH}$. Values are the means \pm $\mathrm{SD}(n=3)$. Significant differences among the various experimental conditions are presented with lower case letters $(\mathbf{a}, \mathbf{b})$

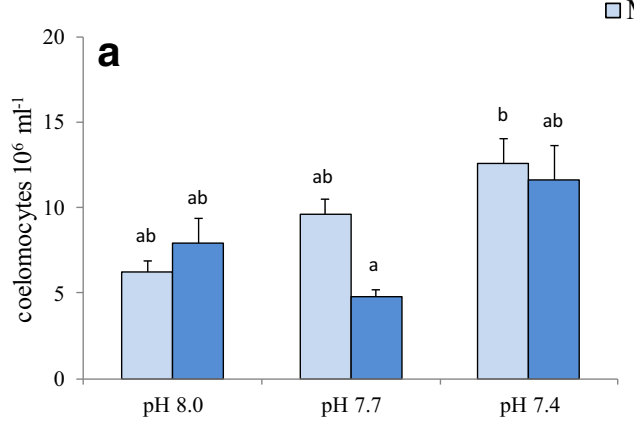

$\square \mathrm{M} \square \mathrm{F}$
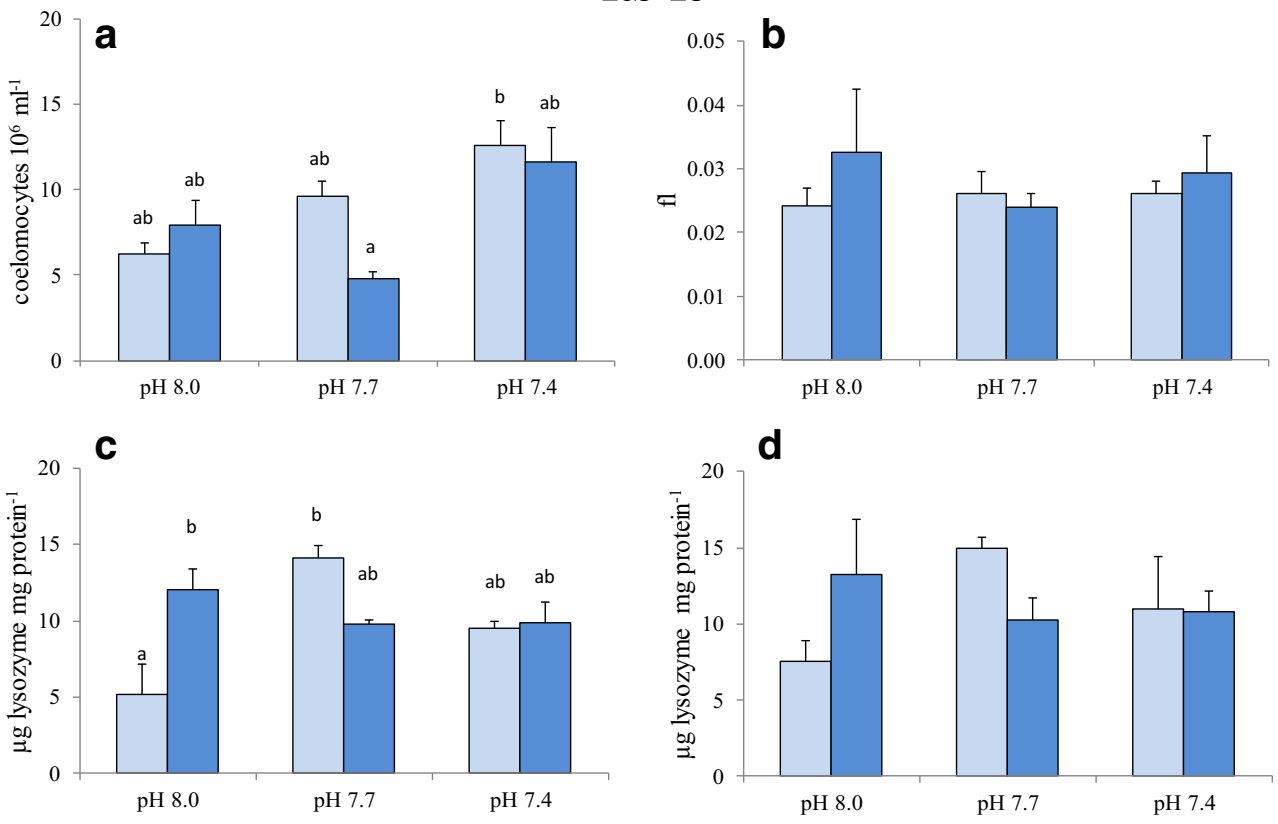

temperature of $10{ }^{\circ} \mathrm{C}$, whereas no differences respect to controls were found at $16{ }^{\circ} \mathrm{C}$. Although in our study $\mathrm{pH}$ significantly influenced respiration rate after 21 days, no significant effects of $\mathrm{pH}$ were observed after 40 days of exposure. This suggested that both male and female $P$. lividus have the potential to acclimate at low $\mathrm{pH}$ conditions after prolonged exposure, as already observed for the same species, both in a laboratory 2-months exposure (Cohen-Rengifo et al. 2019) and in specimens from $\mathrm{CO}_{2}$ vents at Ischia Island (Migliaccio et al. 2019). Similarly, in other species, namely E. mathaei, Strongylocentrotus fragilis, Strongylocentrotus droebachiensis, and Echinometra sp. A, respiration rate was not affected by reduced $\mathrm{pH}$ following long-term exposures (from 49 to 140 days) (Stumpp et al. 2012; Moulin et al. 2014; Taylor et al. 2014; Uthicke et al. 2014). In addition, results obtained after prolonged exposure (more than 5 months) highlighted the capability of Hemicentrotus pulcherrimus and Sterechinus neumayeri to acclimate to low pH conditions (Kurihara et al. 2013; Suckling et al. 2015). However, significant effects of low $\mathrm{pH}$ on sea urchin metabolic rate are reported in the literature, following exposures that lasted no longer than 5 months. For example, in Echinometra mathaei and Anthocidaris crassispina, oxygen uptake was found significantly reduced under OA conditions lasted 42 and 140 days, respectively (Uthicke et al. 2013; Wang et al. 2013). Conversely, in Sterechinus neumayeri and Heliocidaris erythrogramma oxygen consumption increased after exposure for 30 , and 60 days to reduced $\mathrm{pH}$ (Suckling et al. 2015; Carey et al. 2016). Overall, these data highlight that capability of sea urchins to acclimate to low $\mathrm{pH}$ is species- and exposure duration-dependent.

Ammonia production is an indicator of protein metabolism and it was hypothesized that under acidified conditions increased ammonia excretion could act as an additional acid extrusion mechanism in mussels (Thomsen and Melzner 2010) and sea urchins (Stumpp et al. 2012). In this study, after 14 days of exposure, ammonia production was not significantly affected by $\mathrm{pH}$, but it was significantly different between sexes with higher values in males. However, after 21 days, the effect of $\mathrm{pH}$ was significant, with decreasing trend at low $\mathrm{pH}$ conditions in both sexes, even though ammonia excretion decreased at $7.4 \mathrm{pH}$ in males and at $7.7 \mathrm{pH}$ in females.
Fig. 4 Righting time (a) and gonadosomatic index (b) of $P$. lividus males $(\mathrm{M})$ and females (F) after 60-day exposure to 8.0, 7.7 and $7.4 \mathrm{pH}$. Values are the means $\pm \mathrm{SD}(n=3)$. Significant differences among the various experimental conditions are presented with lower case letters (a, b)
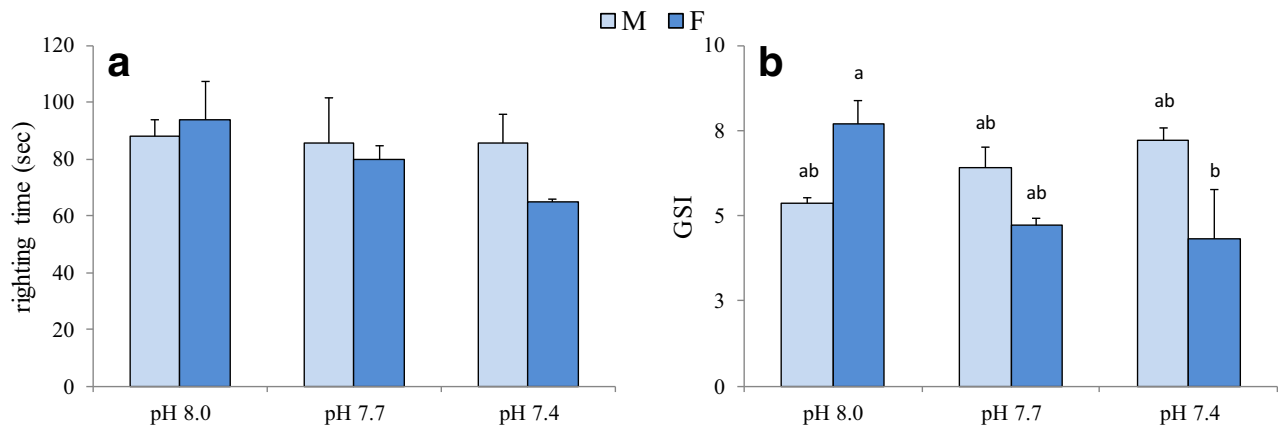


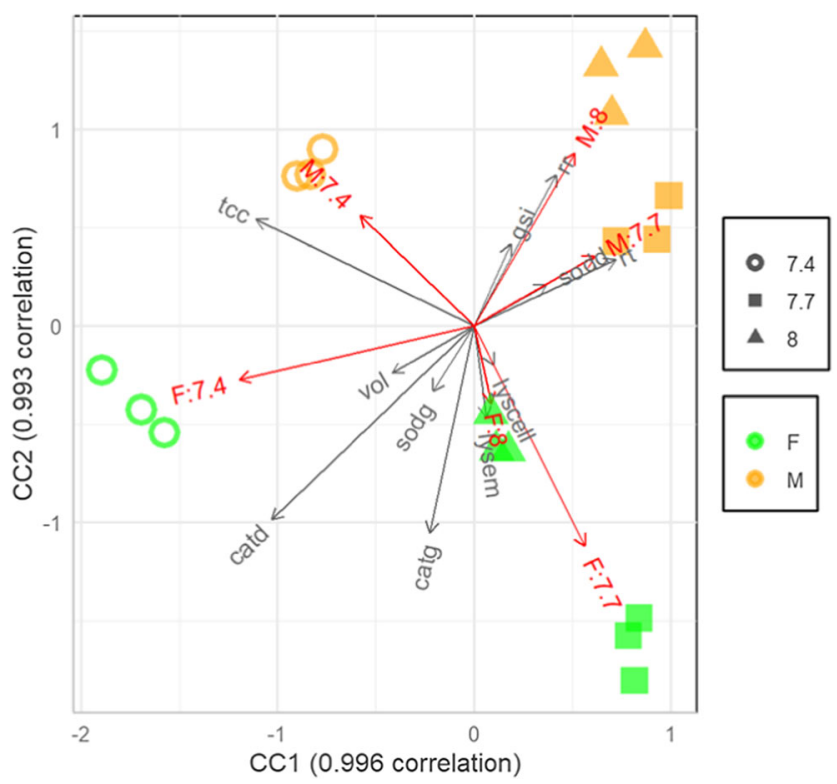

Fig. 5 Canonical correlation analysis of the biomarker dataset. M:8.0, M:7.7, M:7.4: males at $\mathrm{pH}$ 8.0, 7.7 and 7.4, respectively; F:8.0, F:7.7, F:7.4: females at $\mathrm{pH} 8.0,7.7$ and 7.4, respectively. Abbreviations: respiration rate (rr), superoxide dismutase (sod), catalase (cat), gonads (g), digestive tract (d), total coelomocyte count (tcc), coelomocyte volume (vol), lysozyme (lys), cell-free coelomic fluid (em), coelomocytes (cell), righting time (rt) and gonadosomatic index (gsi)

Unfortunately, ammonia excretion data from 40-day-exposed sea urchins lack in our study. Consequently, a more exhaustive conclusion about such physiological parameter cannot be formulated. In this regard, it is important to highlight that exposure for 70 days to $860-940 \mu \mathrm{Atm} \mathrm{CO}_{2}$ did not affect ammonia production in Echinometra sp. A (Uthicke et al. 2014). Similar results were obtained in P. lividus from the vent and non-vent areas at Ischia Island (Migliaccio et al. 2019).

In our study, assimilation efficiency was the only physiological parameter significantly affected after 7 days of exposure. Indeed, a significant interaction between $\mathrm{pH}$ and sex was found, suggesting higher assimilation of organic matter from the food by females when exposed to low $\mathrm{pH}$, while an opposite tendency was observed in males. Similarly to what was observed in males in this study, Siikavuopio et al. (2007) reported decreased assimilation in $S$. droebachiensis exposed for 56 days to $6.98 \mathrm{pH}$. Conversely, in the same species Stumpp et al. (2012) found that the assimilation efficiency was not affected after 10- and 45-days exposure to moderate $(1007-1431 \mu \mathrm{Atm})$ and high $(2800-3800 \mu \mathrm{Atm}) \mathrm{pCO}_{2}$.

Maintenance of antioxidant and immune defence is essential to ensure animal health in acidified seawater. SOD and CAT are considered the primary antioxidant enzymes. They prevent oxidative damage removing reactive oxygen species (ROS) produced during normal metabolism and after oxidative injury. In particular, SOD dismutates superoxide anion $\left(\mathrm{O}_{2}{ }^{-}\right)$to hydrogen peroxide $\left(\mathrm{H}_{2} \mathrm{O}_{2}\right)$ and $\mathrm{O}_{2}$, and CAT is the most important $\mathrm{H}_{2} \mathrm{O}_{2}$ scavenger in cells and reduces $\mathrm{H}_{2} \mathrm{O}_{2}$ to water and $\mathrm{O}_{2}$. In this study, SOD activity in both gonads and digestive tract did not vary significantly owing to either $\mathrm{pH}$ exposure or animal sex. In the study of Amri et al. (2017), a seasonal assessment of antioxidant activities in gonads of $P$. lividus showed highest levels of SOD activity in spring, when GSI reached its maximum value. Conversely, our results did not highlight a similar relationship between SOD activity and GSI. Unlike SOD, CAT activity was significantly different between sexes, with higher values in both gonads and digestive tract from females. Moreover, gonad CAT activity and GSI exhibited a similar pattern of variation in both females and males, suggesting increasing enzyme activity with increasing gonad development. The important role of CAT in gonad antioxidant defence is mirrored in higher activity levels respect to SOD, as observed in this and in previous studies on P. lividus (Perez-Trigo et al. 1995). A prevailing role of CAT against oxidative stress is also confirmed in digestive tract results. Indeed, in both sexes, the enzyme activity increases with increasing stress conditions due to low $\mathrm{pH}$. Contrary to what was observed by Amri et al. 2017, in this study increased CAT activity does not match increased SOD activity. Interestingly, under low $\mathrm{pH}$ and high-temperature values, a general increase in CAT activity was also shown in two bivalves, the clam Chamelea gallina and the mussel Mytilus galloprovincialis (Matozzo et al. 2013). To support the statement of responsiveness of CAT activity to environmental stressors, it is important to highlight that increased enzyme activity was found in gonads of $P$. lividus from areas subject to several industrial activities, and the increase was higher in male specimens (Boussoufa et al. 2017). Although sex-related differences in oxidative stress responses to increased temperature and reduced $\mathrm{pH}$ have recently been reported for the marine gastropod Trochus histrio (Grilo et al. 2018), similar information is lacking for sea urchins, to our knowledge at least.

The sea urchin coelomic fluid contains coelomocytes, circulating cells that have various roles, ranging from immunity to metabolite transport (Endean 1966). Coelomocytes are involved in the immune defence through several processes, such as phagocytosis, coagulation, encapsulation, cytotoxicity and production of antimicrobial agents and other humoral factors (Silva 2013). Coelomocyte number and cell type proportion, as well as many functional responses, vary with the species and the physiological conditions of individuals, as a response to environmental factors, pollutants, pathogens or accidental injuries (Matranga et al. 2000; Pinsino et al. 2007; RamírezGomez et al. 2010). Exposure of P. lividus to pollutants, such as lindane and zinc, or accidental injuries induced an increase in red spherula cells, considered as primary cells possibly affected by stressful conditions (Matranga et al. 2000; Pagliara and Stabili 2012; Stabili and Pagliara 2015).

Among environmental stressors, the effects of exposure to near-future OA on the sea urchins' immune parameters have 
been investigated in some recent studies. Alterations in coelomocyte proportions/number and immune functions, such as phagocytic capacity, cell spreading, bacterial growth inhibition capacity, total antioxidant capacity, and nitric oxide production, have been reported (Dupont and Thorndyke 2012; Brothers et al. 2016; Leite Figueiredo et al. 2016; Migliaccio et al. 2019). In this study, no differences in coelomocyte number and volume between sexes were found, but 60-day exposure induced a significant increase in coelomocyte number of both males and females in the extreme experimental condition tested $(7.4 \mathrm{pH})$. Similarly, a significant increase in coelomocyte number with no differences in cell-type proportions was observed in $L$. variegatus exposed for 5 days to $7.3 \mathrm{pH}$ (Leite Figueiredo et al. 2016). Despite coelomocyte number remained unchanged in Echinometra lucunter and E. droebachiensis, exposure to low $\mathrm{pH}$ induced an increase in phagocytic amoebocytes and a decrease in vibratile cells (Dupont and Thorndyke 2012; Leite Figueiredo et al. 2016). No differences in coelomocyte number and type proportion were found in P. lividus from $\mathrm{CO}_{2}$ vents and control sites at Ischia Island, even though enhanced defensive abilities were revealed in specimens living under reduced $\mathrm{pH}$ (Migliaccio et al. 2019). Among immunomarkers, lysozyme, one of the most important lysosomal hydrolase, is synthesized in coelomocytes and released into the coelomic fluid as a defence mechanism against pathogens and other foreign substances (Stabili et al. 1996). In this study, in both cell-free coelomic fluid and coelomocytes, a significant interaction between $\mathrm{pH}$ and sex induced an opposite pattern of variation in males and females when exposed to low $\mathrm{pH}$, with increased activity in males, at 7.7 $\mathrm{pH}$ in particular, and decreased activity in females. In control conditions, higher lysozyme activity in females respect to males suggested a better immunosurveillance possibly related to different reproductive requirements in the two sexes. Our results match those of Arizza et al. (2013) reporting higher levels of immune activities (cytotoxic, haemolytic and agglutinating) in females of $P$. lividus, together with a higher number of coelomocytes. Since in our study TCC did not differ significantly in females and males, higher lysozyme activity in females seems to be constitutive. Under reduced $\mathrm{pH}$, increased levels in male CFC lysozyme activity in the absence of pathogen challenge could be due to reduced membrane stability of coelomocytes, even though attempts to increase immunosurveillance at the peripheral level cannot be excluded. Unlike males, females exposed to low $\mathrm{pH}$ showed decreased lysozyme activity levels in both $\mathrm{CL}$ and CFC, suggesting a reduction in energy expenditure through decreased lysozyme secretion. Different strategies in males and females coping with ocean acidification likely occur because of different constitutive levels of the enzyme in the two sexes.

The righting response reflects the general physiological state of the echinoderms when subject to environmental changes and it has been used as an indicator of stress and organism well-being (Lawrence and Cowell 1996). This behaviour is neuromuscular-mediated and represents the coordination ability between tube foot and spine (Bayed et al. 2005). In $P$. lividus, righting time was shown to be possibly related to the reproductive status, with increasing values during gonad development and decreasing values after spawning (Bayed et al. 2005). Other authors highlighted the presence of sublethal effects on $P$. lividus righting time, due to oil pollution (Axiak and Saliba 1981). In our experiment, at the control condition, both male and female righting time was close to the reference value (100 s) reported by Axiak and Saliba (1981) for P. lividus. At low $\mathrm{pH}$ values, in males righting time remained unchanged, while in females it was reduced on average to $75 \mathrm{~s}$ at $7.7 \mathrm{pH}$, and $69 \mathrm{~s}$ at $7.4 \mathrm{pH}$. However, the $\mathrm{pH}$ effect observed in females was not statistically significant suggesting that reduced $\mathrm{pH}$ does not affect righting time in $P$. lividus, as observed in juveniles and adults of L. variegatus (Challener and McClintock 2013; Emerson et al. 2017). Only extremely low pH (6.6) negatively affected righting time in $S$. fragilis (Taylor et al. 2014). Other behavioural aspects in P.lividus were recently investigated by Cohen-Rengifo et al. (2019). They showed that podia adhesion strength was not influenced by reduced $\mathrm{pH}$ and highlighted positive synergistic effects of ocean acidification and ocean warming on sea urchin moving velocity at $7.7 \mathrm{pH}$, but not at $7.4 \mathrm{pH}$. It was hypothesized that the observed behavioural modifications were ascribed to the accumulation of $\mathrm{HCO}_{3}{ }^{-}$ in extracellular fluid, as protection against acidosis, and to the compensatory reduction of $\mathrm{Cl}^{-}$(Stumpp et al. 2012; Collard et al. 2014). Alterations in the concentration of these ions could influence GABA receptors, which are involved in neurological mechanisms, such as information processing (Cohen-Rengifo et al. 2019). Potential modifications of sea urchin behaviour under reduced $\mathrm{pH}$ deserve further attention in future studies. Interestingly, in our study female righting time and GSI exhibited the same pattern of variation with decreasing $\mathrm{pH}$ value.

According to Luís et al. (2005), 2 months were enough to allow gonad maturation and spawning in P. lividus after a previous $\mathrm{KCl}$ spawning induction, and the observed GSI values were in the range reported for ripe sea urchins in natural populations (Gago et al. 2003). In sea urchins, gonad development is affected by various abiotic and biotic factors, such as temperature (Delorme and Sewell 2016; Zhao et al. 2016; Yeruham et al. 2019), pH (Stumpp et al. 2012; Kurihara et al. 2013; Taylor et al. 2014), photoperiod (Shpigel et al. 2004), food availability and quality (Murillo-Navarro and JiménezGuirado 2012; Prato et al. 2018), hydrodynamism (Gianguzza et al. 2013) and pollutants (Schäfer and Köhler 2009; RouaneHacene et al. 2018). Sea urchin gonads are very plastic organs that can be used as energy storage: they can be filled or depleted depending on animal conditions. Under stressful 
conditions, the effects observed are often species-specific and mostly dependent on the type and duration of the stress occurred. Although no differences in GSI are generally reported in males and females from natural populations (Guettaf and San Martin 1995; Gago et al. 2003; Luís et al. 2005), there is increasing evidence of sex-related differences under stressful conditions. Accordingly, in this study, no difference between sexes was found at $8.0 \mathrm{pH}$; however, an opposite effect on GSI was observed in the two sexes at low $\mathrm{pH}$, with a significant decrease at $7.4 \mathrm{pH}$ in females and an increasing trend at low $\mathrm{pH}$ values in males. In a previous study, RNA/DNA ratio, an indicator of gonadal production, was higher in female than in male gonads of $P$. lividus, but in both sexes no differences were observed after exposure for 19 days to 8.0, 7.7 and 7.4 pH (Catarino et al. 2012). Conversely, in E. mathaei maintained for 6 weeks at similar $\mathrm{pH}$ values, a reduced spawning ability was observed in males kept at low $\mathrm{pH}$, whereas in females both spawning ability and oocyte size did not change (Uthicke et al. 2013). In Echinometra sp. A, gonad index was not affected by a 77-day exposure at low $\mathrm{pH}$, but a synergistic effect of decreased $\mathrm{pH}$ and increased temperature was revealed in both sexes, and males appeared more sensitive to low pH (Uthicke et al. 2014). After 9-month exposure to elevated $\mathrm{pCO}_{2}$, Hemicentrotus pulcherrimus showed a 1-month delay in gonad maturation and spawning, even though the maximum number of eggs was not affected (Kurihara et al. 2013). Gonad growth was reduced after 45- and 56-day exposure at low pH in S. droebachiensis (Siikavuopio et al. 2007; Stumpp et al. 2012) and after 140 days in S. fragilis (Taylor et al. 2014). Although several studies reported negative effects of reduced $\mathrm{pH}$ on sea urchin gonad growth, GSI reduction under low $\mathrm{pH}$ observed in this study in P. lividus females could be indicative of more detrimental effects arising from greater energy request to maintain homeostasis, with a consequent reduction in energy to invest in reproduction.

Overall, this study highlighted the presence of differences between sexes under control conditions and male and female sea urchins often responded differently to OA. As shown in $\mathrm{CCA}$ results, at $8.0 \mathrm{pH}$, sexes are clearly separated along the second canonical component, differing in CAT activity in both the digestive tract and gonads (higher in females), coelomocyte parameters (lysozyme activity in both coelomocytes and haemolymph, and coelomocyte volume higher in females) and metabolism (higher in males). In both sexes, a clear spatial distribution was observed according to $\mathrm{pH}$ values along the first canonical component. With increasing seawater acidity, enhanced CAT activity and decreased metabolism were observed in females. Females appeared more sensitive to $\mathrm{pH}$ variations with a clear separation between controls and reduced $\mathrm{pH}$ treatments. In females, low $\mathrm{pH}, 7.4$ in particular, led to enhanced antioxidant defence in the digestive tract (with increased CAT activity), modified behaviour (with a reduction of righting time) and reduced energy investment in reproduction (with a gonadosomatic index decrease). Since the pattern of separation was opposite in females and males, the latter showed reduced antioxidant activity in gonads, reduced coelomocyte volume and lysozyme activity and increased metabolism. At extremely low $\mathrm{pH}$ condition (7.4), both males and females exhibited the highest value of coelomocyte number.

\section{Conclusions}

In this study, different responses to OA were observed in males and females of $P$. lividus. However, responses appeared to be mostly influenced by basal differences between genders. Males exhibited lower protective levels in antioxidant and immune defence, and when subject to reduced $\mathrm{pH}$ they appeared to tackle this deficiency by somehow reducing metabolic expenditure. Conversely, females having a better basal protection against stress differently modulated antioxidant and immune-related responses but reduced their reproductive potential. Sex-specific differences, likely reflecting adaptive mechanisms of gametes with different life span, very short in sperm and long in eggs, can be important drivers affecting responses to environmental stress. For this reason, further research is needed to shed more light on the strengths and weaknesses of male and female sea urchins under global change scenarios.

Acknowledgements Open access funding provided by Università degli Studi di Padova within the CRUI-CARE Agreement. The authors wish to thank Prof. Livio Finos for his valuable support in the statistical analyses of data. Thanks are also extended to Mr. Mohamad Sofi Abu Hassan and Mrs. Nik Nurasyikin Nik Mohmmad Azmi for their technical assistance in biochemical analyses.

Open Access This article is licensed under a Creative Commons Attribution 4.0 International License, which permits use, sharing, adaptation, distribution and reproduction in any medium or format, as long as you give appropriate credit to the original author(s) and the source, provide a link to the Creative Commons licence, and indicate if changes were made. The images or other third party material in this article are included in the article's Creative Commons licence, unless indicated otherwise in a credit line to the material. If material is not included in the article's Creative Commons licence and your intended use is not permitted by statutory regulation or exceeds the permitted use, you will need to obtain permission directly from the copyright holder. To view a copy of this licence, visit http://creativecommons.org/licenses/by/4.0/.

\section{References}

Aebi H (1984) Catalase in vitro. Method Enzymol 105:121-126

Amri S, Samar MF, Sellem F, Ouali K (2017) Seasonal antioxidant responses in the sea urchin Paracentrotus lividus (Lamarck 1816) used as a bioindicator of the environmental contamination in the South-East Mediterranean. Mar Pollut Bull 122:392-402 
Arizza V, Vazzana M, Schillaci D, Russo D, Giaramita FT, Parrinello N (2013) Gender differences in the immune system activities of sea urchin Paracentrotus lividus. Comp Biochem Physiol 164A:447455

Axiak V, Saliba LJ (1981) Effects of surface and sunken crude oil on the behaviour of a sea urchin. Mar Pollut Bull 12:14-19

Bayed A, Quiniou F, Benrha A, Guillou M (2005) The Paracentrotus lividus populations from the northern Moroccan Atlantic coast: growth, reproduction and health condition. J Mar Biol Assoc UK 85:999-1007

Benedetti M, Lanzoni I, Nardi A, d'Errico G, Di Carlo M, Fattorini D, Nigro M, Regoli F (2016) Oxidative responsiveness to multiple stressors in the key Antarctic species, Adamussium colbecki: interactions between temperature, acidification and cadmium exposure. Mar Environ Res 121:20-30

Boudouresque CF, Verlaque M (2013) Paracentrotus lividus. In: Lawrence JM (ed) Sea urchins: biology and ecology, developments in aquaculture and fisheries science. Elsevier, Amsterdam, pp 297 327

Boussoufa D, Chalouati H, Feriel G, Safa B, El Cafsi M (2017) Assessment of sex-related variability of biomarkers in sea urchin (Paracentrotus lividus) from Bizerte lagoon, Tunisia. Toxicol Lett 280(Suppl. 1):S213

Bradford MM (1976) A rapid and sensitive method for the quantitation of microgram quantities of protein utilizing the principle of protein dye binding. Anal Biochem 72:248-254

Brothers CJ, Harianto J, McClintock JB, Byrne M (2016) Sea urchins in a high- $\mathrm{CO}_{2}$ world: the influence of acclimation on the immune response to ocean warming and acidification. Proc R Soc B 283: 20161501

Byrne M (2012) Global change ecotoxicology: identification of early life history bottlenecks in marine invertebrates, variable species responses and variable experimental approaches. Mar Environ Res $76: 3-15$

Byrne M, Hernández JC (2020) Sea urchins in a high CO2 world: impacts of climate warming and ocean acidification across life history stages. In: Lawrence JM (ed) Sea urchins: biology and ecology, developments in aquaculture and fisheries science. Elsevier, Amsterdam, pp 281-297

Calosi P, Rastrick SPS, Graziano M, Thomas SC, Baggini C, Carter HA, Hall-Spencer JM, Milazzo M, Spicer JI (2013) Distribution of sea urchins living near shallow water $\mathrm{CO} 2$ vents is dependent upon species acid-base and ion-regulatory abilities. Mar Pollut Bull 73: $470-484$

Campbell AL, Levitan DR, Hosken DJ, Lewis C (2016) Ocean acidification changes the male fitness landscape. Sci Rep 6:31250

Cardoso PG, Grilo TF, Dionísio G, Aurélio M, Lopes AR, Pereira R, Pacheco M, Rosa R (2017) Short-term effects of increased temperature and lowered $\mathrm{pH}$ on a temperate grazer-seaweed interaction (Littorina obtusata/Ascophyllum nodosum). Estuar Coast Shelf Sci 197:35-44

Carey N, Harianto J, Byrne M (2016) Urchins in a high $\mathrm{CO}_{2}$ world: partitioned effects of body-size, ocean warming and acidification on metabolic rate. J Exp Biol 219:1178-1186

Cassin D, Dominik J, Botter M, Zonta R (2018) PAH and PCB contamination in the sediments of the Venice Lagoon (Italy) before the installation of the MOSE flood defence works. Environ Sci Pollut Res 25:24951-24964

Catarino AI, Bauwens M, Dubois P (2012) Acid-base balance and metabolic response of the sea urchin Paracentrotus lividus to different seawater $\mathrm{pH}$ and temperatures. Environ Sci Pollut Res 19:2344 2353

Challener RC, McClintock JB (2013) Exposure to extreme hypercapnia under laboratory conditions does not impact righting and covering behavior of juveniles of the common sea urchin Lytechinus variegatus. Mar Fresh Behav Physiol 46:191-199
Cohen-Rengifo M, García E, Hernández CA, Hernández JC, Clemente S (2013) Global warming and ocean acidification affect fertilization and early development of the sea urchin Paracentrotus lividus. Cah Biol Mar 54:667-675

Cohen-Rengifo M, Agüera A, Bouma T, M'Zoudi S, Flammang P, Dubois P (2019) Ocean warming and acidification alter the behavioral response to flow of the sea urchin Paracentrotus lividus. Ecol Evol 9:12128-12143

Collard M, Laitat K, Moulin L, Catarino AI, Grosjean P, Dubois P (2013) Buffer capacity of the coelomic fluid in echinoderms. Comp Biochem Physiol 166A:199-206

Collard M, Dery A, Dehairs F, Dubois P (2014) Euechinoidea and Cidaroidea respond differently to ocean acidification. Comp Biochem Physiol 174(A):45-55

Collard M, Rastrick SPS, Calosi P, Demolder Y, Dille J, Findlay HS, Hall-Spencer JM, Milazzo M, Moulin L, Widdicombe S, Dehairs F, Dubois P (2016) The impact of ocean acidification and warming on the skeletal mechanical properties of the sea urchin Paracentrotus lividus from laboratory and field observations. ICES J Mar Sci 73: $727-738$

Conover RJ (1966) Assimilation of organic matter by zooplankton. Limnol Oceanogr 11:338-345

Crapo JD, McCord JM, Fridovich I (1978) Preparation and assay of superoxide dismutases. Method Enzymol 53:382-393

Delorme NJ, Sewell MA (2016) Effects of warm acclimation on physiology and gonad development in the sea urchin Evechinus chloroticus. Comp Biochem Physiol 198A:33-40

Dickson AG, Afghan JD, Anderson GC (2003) Reference materials for oceanic $\mathrm{CO}_{2}$ analysis: a method for the certification of total alkalinity. Mar Chem 80:185-197

Dupont ST, Thorndyke MS (2012) Relationship between $\mathrm{CO}_{2}$-driven changes in extracellular acid-base balance and cellular immune response in two polar echinoderm species. J Exp Mar Biol Ecol 424 425:32-37

Dupont S, Dorey N, Stumpp M, Melzner F, Thorndyke M (2013) Longterm and trans-life-cycle effects of exposure to ocean acidification in the green sea urchin Strongylocentrotus droebachiensis. Mar Biol 160:1835-1843

Dworjanyn SA, Byrne M (2018) Impacts of ocean acidification on sea urchin growth across the juvenile to mature adult life-stage transition is mitigated by warming. Proc R Soc B Biol Sci 285:1-10

Ellis RP, Spicer JI, Byrne J, Sommer U, Viant MR, White D, Widdicombe S (2014) 1H NMR metabolomics reveals contrasting response by male and female mussels exposed to reduced seawater $\mathrm{pH}$, increased temperature and a pathogen. Environ Sci Technol 48: 7044-7052

Ellis RP, Davison W, Queirós AM, Kroeker KJ, Calosi P, Dupont S, Spicer JI, Wilson RW, Widdicombe S, Urbina MA (2017) Does sex really matter? Explaining intraspecies variation in ocean acidification responses. Biol Lett 13:20160761

Emerson CE, Reinardy HC, Bates NR, Bodnar AG (2017) Ocean acidification impacts spine integrity but not regenerative capacity of spines and tube feet in adult sea urchins. R Soc Open Sci 4:170140

Endean R (1966) The coelomocytes and coelomic fluids. In: Boolootian RA (ed) Physiology of Echinodermata. Interscience Publishers, New York, pp 301-328

Fernández-Boo S, Pedrosa-Oliveira MH, Afonso A, Arenas F, Rocha F, Valente LMP, Costa B (2018) Annual assessment of the sea urchin (Paracentrotus lividus) humoral innate immune status: tales from the north Portuguese coast. Mar Environ Res 141:128-137

Finos L (2020) r41sqrt10: livio's sandbox. R package version 0.1

Freitas R, De Marchi L, Bastos M, Moreira A, Velez C, Chiesa S, Wrona FJ, Figueira E, Soaresa AMVM (2017a) Effects of seawater acidification and salinity alterations on metabolic, osmoregulation and oxidative stress markers in Mytilus galloprovincialis. Ecol Indic 79: $54-62$ 
Freitas R, De Marchi L, Moreira A, Pestana JLT, Wrona FJ, Figueira E, Soares AMVM (2017b) Physiological and biochemical impacts induced by mercury pollution and seawater acidification in Hediste diversicolor. Sci Total Environ 595:691-701

Gago J, Luís OJ (2011) Comparison of spawning induction techniques on Paracentrotus lividus (Echinodermata: Echinoidea) broodstock. Aquacult Int 19:181-191

Gago J, Range P, Luís OJ (2003) Growth, reproductive biology and habitat selection of the sea urchin Paracentrotus lividus in the coastal waters of Cascais, Portugal. In: Féral JP, David B (eds) Echinoderm research 2001. Swets \& Zeitlinger, Lisse, pp 269-276

Gianguzza P, Bonaviri C, Prato E, Fanelli G, Chiantore M, Privitera D, Luzzu F, Agnetta D (2013) Hydrodynamism and its influence on the reproductive condition of the edible sea urchin Paracentrotus lividus. Mar Environ Res 85:29-33

Glippa O, Engström-Öst J, Kanerva M, Rein A, Vuori K (2018) Oxidative stress and antioxidant defense responses in Acartia copepods in relation to environmental factors. PLoS One 13(4): e0195981

González I, Déjean S (2012) CCA: canonical correlation analysis. R package version $1.2 \mathrm{http} / / / C R A N$.R-project.org/package=CCA

Graham H, Rastrick SPS, Findlay HS, Bentley MG, Widdicombe S, Clare AS, Caldwell GS (2015) Sperm motility and fertilisation success in an acidified and hypoxic environment. ICES J Mar Sci 73(3): 783-790

Grilo TF, Lopes AR, Sampaio E, Rosa R, Cardoso PG (2018) Sex differences in oxidative stress responses of tropical topshells (Trochus histrio) to increased temperature and high $\mathrm{pCO}_{2}$. Mar Pollut Bull 131:252-259

Grosjean P, Spirlet C, Gosselin P, Vaitilingon D, Jangoux M (1998) Land-based, closed-cycle echiniculture of Paracentrotus lividus (Lamarck) (Echinoidea: Echinodermata): a long-term experiment at a pilot scale. J Shellfish Res 17:1523-1531

Guettaf M, San Martin GA (1995) Étude de la variabilité de l'indice gonadique de l'oursin comestible Paracentrotus lividus (Echinodermata: Echinidae) en Méditerranée Nord-Occidentale. Vie Milieu 45:129-137

Hall-Spencer JM, Thorndyke M, Dupont S (2015) Impact of ocean acidification on marine organisms-unifying principles and new paradigms. Water 7:5592-5598

Hartin CA, Bond-Lamberti B, Patel P, Mundra A (2016) Ocean acidification over the next three centuries using a simple global climate carbon-cycle model: projections and sensitivities. Biogeosciences 13:4329-4342

Hereu B (2006) Depletion of palatable algae by sea urchins and fishes in a Mediterranean subtidal community. Mar Ecol Prog Ser 313:95-103

Holtmann WC, Stumpp M, Gutowska MA, Syré S, Himmerkus N, Melzner F, Bleich M (2013) Maintenance of coelomic fluid pH in sea urchins exposed to elevated $\mathrm{CO}_{2}$ : the role of body cavity epithelia and stereom dissolution. Mar Biol 160:2631-2645

Huang X, Liu Z, Xie Z, Dupont S, Huang W, Wu F, Kong H, Liu L, Sui Y, Lin D, Lu W, Hu M, Wang Y (2018) Oxidative stress induced by titanium dioxide nanoparticles increases under seawater acidification in the thick shell mussel Mytilus coruscus. Mar Environ Res $37: 49-59$

Ingle SE (1975) Solubility of calcite in the ocean. Mar Chem 3:301-319

IPCC (2013) Climate change 2013: the physical science basis. In: Stocker TF, Qin D, Plattner GK, Tignor M, Allen SK, Boschung J, Nauels A, Xia Y, Bex V, Midgley PM (eds) Contribution of working group I to the fifth assessment report of the intergovernmental panel on climate change. Cambridge University Press, Cambridge, p 1535

IPCC (2019) Summary for policymakers. In: Pörtner HO, Roberts DC, Masson-Delmotte V, Zhai P, Tignor M, Poloczanska E, Mintenbeck K, Alegría A, Nicolai M, Okem A, Petzold J, Rama B, Weyer NM (eds.) IPCC Special report on the ocean and cryosphere in a changing climate. In press
Karelitz S, Lamare M, Patel F, Gemmell N, Uthicke S (2020) Parental acclimation to future ocean conditions increases development rates but decreases survival in sea urchin larvae. Mar Biol 167:2. https:// doi.org/10.1007/s00227-019-3610-5

Klein RD, Nogueira LS, Domingos-Moreira FXV, Gomes Costa P, Bianchini A, Wood CM (2019) Effects of sublethal Cd, Zn, and mixture exposures on antioxidant defense and oxidative stress parameters in early life stages of the purple sea urchin Strongylocentrotus purpuratus. Aquat Toxicol 217:105338

Kurihara H, Yin R, Nishihara GN, Soyano K, Ishimatsu A (2013) Effect of ocean acidification on growth, gonad development, and physiology: of the sea urchin Hemicentrotus pulcherrimus. Aquat Biol 18: 281-292

Lane A, Campanati C, Dupont S, Thiyagarajan V (2015) Transgenerational responses to low $\mathrm{pH}$ depend on parental gender in a calcifying tubeworm. Sci Rep 5:10847

Lawrence JM, Cowell BC (1996) The righting response as an indication of stress in Stichaster striatus (Echinodermata, Asteroidea). Mar Fresh Behav Physiol 27:239-248

Leite Figueiredo DA, Branco PC, dos Santos DA, Emerenciano AK, Iunes RS, Shimada Borges JC, Machado Cunha da Silva JR (2016) Ocean acidification affects parameters of immune response and extracellular $\mathrm{pH}$ in tropical sea urchins Lytechinus variegatus and Echinometra luccunter. Aquat Toxicol 180:84-94

Lewis C, Ellis RP, Vernon E, Elliot K, Newbatt S, Wilson RW (2016) Ocean acidification increases copper toxicity differentially in two key marine invertebrates with distinct acid-base responses. Sci Rep 6:21554

Luís O, Delgado F, Gago J (2005) Year-round captive spawning performance of the sea urchin Paracentrotus lividus: relevance for the use of its larvae as live feed. Aquat Living Resour 18:45-54

Matozzo V, Chinellato A, Munari M, Bressan M, Marin MG (2013) Can the combination of decreased $\mathrm{pH}$ and increased temperature values induce oxidative stress in the clam Chamelea gallina and the mussel Mytilus galloprovincialis? Mar Pollut Bull 72:34-40

Matranga V, Toia G, Bonaventura R, Muller WEG (2000) Cellular and biochemical responses to environmental and experimentally induced stress in sea urchin coelomocytes. Cell Stress Chaperon 5: $158-165$

McClellan-Green P, Romano J, Oberdörster E (2007) Does gender really matter in contaminant exposure? A case study using invertebrate models. Environ Res 104:183-191

Melzner F, Gutowska MA, Langenbuch M, Dupont S, Lucassen M, Thorndyke MC, Bleich M, Pörtner HO (2009) Physiological basis for high $\mathrm{CO}_{2}$ tolerance in marine ectothermic animals: preadaptation through lifestyle and ontogeny? Biogeosciences 6:2313-2331

Migliaccio O, Pinsino A, Maffioli E, Smith AM, Agnisola C, Matranga V, Nonnis S, Tedeschi G, Byrne M, Gambi MC, Palumbo A (2019) Living in future ocean acidification, physiological adaptive responses of the immune system of sea urchins resident at a $\mathrm{CO}_{2}$ vent system. Sci Total Environ 672:938-950

Miles H, Widdicombe W, Spice JI, Hall-Spencer J (2007) Effects of anthropogenic seawater acidification on acid-base balance in the sea urchin Psammechinus miliaris. Mar Pollut Bull 54:89-96

Millero FJ (1979) The thermodynamics of the carbonic acid system in seawater. Geochim Cosmochim Acta 43:1651-1661

Millero FJ (1995) Thermodynamics of the carbon dioxide system in the oceans. Geochim Cosmochim Acta 59:661-677

Millero FJ, Graham TB, Huang F, Bustos-Serrano H, Pierrot D (2006) Dissociation constants of carbonic acid in seawater as a function of salinity and temperature. Mar Chem 100:80-94

Morse JW, Andersson AJ, Mackenzie FT (2006) Initial response of carbonate-rich shelf sediments to rising atmospheric $p \mathrm{CO}_{2}$ and "ocean acidification": role of high $\mathrm{Mg}$-calcites. Geochim Cosmochim Acta 70:5814-5830 
Mos B, Byrne M, Dworjanyn SA (2016) Biogenic acidification reduces sea urchin gonad growth and increases susceptibility of aquaculture to ocean acidification. Mar Environ Res 113:39-48

Moulin L, Grosjean P, Leblud J, Batigny A, Dubois P (2014) Impact of elevated $\mathrm{pCO}_{2}$ on acid-base regulation of the sea urchin Echinometra mathaei and its relation to resistance to ocean acidification: a study in mesocosms. J Exp Mar Biol Ecol 457:97-104

Mucci A (1983) The solubility of calcite and aragonite in seawater at various salinities, temperatures, and one atmosphere total pressure. Am J Sci 283:780-799

Munari M, Matozzo V, Gagné F, Chemello G, Riedl V, Finos L, Pastore P, Badocco D, Marin MG (2018) Do seawater acidification and diclofenac induce oxidative stress in marine bivalves? A comparison study with the mussel Mytilus galloprovincialis and the clam Ruditapes philippinarum. Environ Pollut 240:925-937

Murillo-Navarro R, Jiménez-Guirado D (2012) Relationships between algal food and gut and gonad conditions in the Mediterranean sea urchin Paracentrotus lividus (Lam.). Mediterr Mar Sci 13:227-238

Nardi A, Mincarelli LF, Benedetti M, Fattorini D, d'Errico G, Regoli F (2017) Indirect effects of climate changes on cadmium bioavailability and biological effects in the Mediterranean mussel Mytilus galloprovincialis. Chemosphere 169:493-502

Pagliara P, Stabili L (2012) Zinc effect on the sea urchin Paracentrotus lividus immunological competence. Chemosphere 89:563-568

Parolini M, Binelli A, Matozzo V, Marin MG (2010) Persistent organic pollutants in sediments from the Lagoon of Venice - a possible hazard for sediment-dwelling organisms. J Soils Sediments 10: $1362-1379$

Parolini M, Binelli A, Marin MG, Matozzo V, Masiero L, Provini A (2012) New evidences in the complexity of contamination of the lagoon of Venice: polybrominated diphenyl ethers (PBDEs) pollution. Environ Monit Assess 184:2001-2015

Perez-Trigo E, Garcia-Martinez P, Catoira JL, Mosquera G (1995) Subcellular distribution of antioxidant enzymes in the gonads of the sea urchin, Paracentrotus lividus Lmk, from Rìa AresBetanzos, NW Spain. In: Emson R, Smith A, Campbell A (eds) Echinoderm research 1995. Balkema, Rotterdam, pp 51-55

Pimentel MS, Faleiro F, Diniz M, Machado J, Pousão-Ferreira P, Peck MA, Pörtner HO, Rosa R (2015) Oxidative stress and digestive enzyme activity of flatfish larvae in a changing ocean. PLoS One 10(7):e0134082

Pinsino A, Thorndyke MC, Matranga V (2007) Coelomocytes and posttraumatic response in the common sea star Asterias rubens. Cell Stress Chaperon 12:331-341

Prato E, Fanelli G, Angioni A, Biandolino F, Parlapiano I, Papa L, Denti G, Secci M, Chiantore M, Kelly MS, Ferranti MP, Addis P (2018) Influence of a prepared diet and a macroalga (Ulva sp.) on the growth, nutritional and sensory qualities of gonads of the sea urchin Paracentrotus lividus. Aquaculture 493:240-250

Privitera D, Chiantore M, Mangialajo L, Glavic N, Kozul V, CattaneoVietti R (2008) Inter- and intra-specific competition between Paracentrotus lividus and Arbacia lixula in resource-limited barren areas. J Sea Res 60:184-192

Priya RJ, Anand M, Maruthupandy M, Beevi AH (2017) Biomarker response of climate change induced ocean acidification and hypercapnia studies on brachyurian crab Portunus pelagicus. Global J Environ Sci Manage 3:165-176

Queirós AM, Fernandes JA, Faulwetter S, Nunes J, Rastrick SPS, Mieszkowska N, Artioli Y, Yool A, Calosi P, Arvanitidis C, Findlay HS, Barange M, Cheung WWL, Widdicombe S (2015) Scaling up experimental ocean acidification and warming research: from individuals to the ecosystem. Glob Chang Biol 21:130-143

R Core Team (2019) R: A language and environment for statistical computing. R Foundation for Statistical Computing, Vienna, Austria. URL https://www.R-project.org
Ramírez-Gomez F, Aponte-Rivera F, Mendez-Castaner L, GarcíaArraras JE (2010) Changes in holothurian coelomocyte populations following immune stimulation with different molecular patterns. Fish Shellfish Immunol 29:175-185

Rato LD, Novais SC, Lemos MFL, Alves LMF, Leandro SM (2017) Homarus gammarus (Crustacea: Decapoda) larvae under an ocean acidification scenario: responses across different levels of biological organization. Comp Biochem Physiol 203C:29-38

Reid GK, Liutkus M, Bennett A, Robinson SMC, MacDonald B, Page F (2010) Absorption efficiency of blue mussels (Mytilus edulis and M. trossulus) feeding on Atlantic salmon (Salmo salar) feed and fecal particulates: implications for integrated multi-trophic aquaculture. Aquaculture 299:165-169

Rouane-Hacene O, Boutiba Z, Benaissa M, Belhaouari B, Francour P, Guibbolini-Sabatier ME, Risso-De Faverney C (2018) Seasonal assessment of biological indices, bioaccumulation, and bioavailability of heavy metals in sea urchins Paracentrotus lividus from Algerian west coast, applied to environmental monitoring. Environ Sci Pollut Res 25:1238-11251

Santarém MM, Robledo JAF, Figueras A (1994) Seasonal changes in hemocytes and serum defense factors in the blue mussel Mytilus galloprovincialis. Dis Aquat Org 18:217-222

Schäfer S, Köhler A (2009) Gonadal lesions of female sea urchin (Psammechinus miliaris) after exposure to the polycyclic aromatic hydrocarbon phenanthrene. Mar Environ Res 68:128-136

Shpigel M, McBride SC, Marciano S, Lupatsch I (2004) The effect of photoperiod and temperature on the reproduction of European sea urchin Paracentrotus lividus. Aquaculture 232:343-355

Siikavuopio SI, Mortensen A, Dale T, Foss A (2007) Effects of carbon dioxide exposure on feed intake and gonad growth in green sea urchin, Strongylocentrotus droebachiensis. Aquaculture 266:97101

Silva JRMC (2013) Immunology in sea urchins. In: Lawrence JM (ed) Sea urchins: biology and ecology, developments in aquaculture and fisheries science. Elsevier, Amsterdam, pp 187-194

Solorzano L (1969) Determination of ammonia in natural waters by the phenolhypochlorite method. Limnol Oceanogr 14:799-801

Soriano-Santiago OS, Liñán-Cabello MA, Delgadillo-Nuño MA, OrtegaOrtiz C, Cuevas-Venegas S (2013) Physiological responses to oxidative stress associated with $\mathrm{pH}$ variations in host tissue and zooxanthellae of hermatypic coral Pocillopora capitata. Mar Freshw Behav Physiol 46:275-286

Spicer J, Widdicombe S (2012) Acute extracellular acid-base disturbance in the burrowing sea urchin Brissopsis lyrifera during exposure to a simulated $\mathrm{CO}_{2}$ release. Sci Total Environ 427-428:203-207

Spicer J, Widdicombe S, Needham H, Berge J (2011) Impact of $\mathrm{CO}_{2^{-}}$ acidified seawater on the extracellular acid-base balance of the northern sea urchin Strongylocentrotus dröebachiensis. J Exp Mar Biol Ecol 407:19-25

Spirlet C, Grosjean P, Jangoux M (2000) Optimization of gonad growth by manipulation of temperature and photoperiod in cultivated sea urchins, Paracentrotus lividus (Lamarck Echinodermata). Aquaculture 185:85-99

Stabili L, Pagliara P (2015) The sea urchin Paracentrotus lividus immunological response to chemical pollution exposure: the case of lindane. Chemosphere 134:60-66

Stabili L, Pagliara P, Roch P (1996) Antibacterial activity in the coelomocytes of the sea urchin Paracentrotus lividus. Comp Biochem Physiol 113B:639-644

Stumpp M, Trübenbach K, Brennecke D, Hu MY, Melzner F (2012) Resource allocation and extracellular acid-base status in the sea urchin Strongylocentrotus droebachiensis in response to $\mathrm{CO}_{2}$ induced seawater acidification. Aquat Toxicol 110-111:194-207

Suckling CC, Clark MS, Beveridge C, Brunner L, Hughes AD, Harper EM, Cook EJ, Davies AJ, Peck LS (2014) Experimental influence of $\mathrm{pH}$ on the early life-stages of sea urchins II: increasing parental 
exposure times gives rise to different responses. Invertebr Reprod Dev 58:61-175

Suckling CC, Clark MS, Richard J, Morley SA, Thorne MAS, Harper EM, Peck LS (2015) Adult acclimation to combined temperature and $\mathrm{pH}$ stressors significantly enhances reproductive outcomes compared to short-term exposures. J Anim Ecol 84:773-784

Sui Y, Hu M, Shang Y, Wu F, Huang X, Dupont S, Storch D, Pörtner HO, Lia J, Lu W, Wang Y (2017) Antioxidant response of the hard shelled mussel Mytilus coruscus exposed to reduced $\mathrm{pH}$ and oxygen concentration. Ecotoxicol Environ Safe 137:94-102

Taylor JR, Lovera C, Whaling PJ, Buck KR, Pane EF, Barry JP (2014) Physiological effects of environmental acidification in the deep-sea urchin Strongylocentrotus fragilis. Biogeosciences 11:1413-1423

Thomsen J, Melzner F (2010) Seawater acidification does not elicit metabolic depression in the blue mussel Mytilus edulis. Mar Biol 157: 2667-2676

Tomanek L, Zuzow MJ, Ivanina AV, Beniash E, Sokolova IM (2011) Proteomic response to elevated $\mathrm{P}_{\mathrm{CO} 2}$ level in eastern oysters, Crassostrea virginica: evidence for oxidative stress. J Exp Biol 214:1836-1844

Uthicke S, Soars N, Foo S, Byrne M (2013) Effects of elevated $\mathrm{pCO}_{2}$ and the effect of parent acclimation on development in the tropical Pacific Sea urchin Echinometra mathaei. Mar Biol 160:1913-1926

Uthicke S, Liddy M, Nguyen HD, Byrne M (2014) Interactive effects of near-future temperature increase and ocean acidification on physiology and gonad development in adult Pacific sea urchin. Echinometra sp. A. Coral Reefs 33:831-845
Velez C, Figueira E, Soares AMVM, Freitas R (2016) Combined effects of seawater acidification and salinity changes in Ruditapes philippinarum. Aquat Toxicol 176:141-150

Wang G, Yagi M, Yin R, Lu W, Ishimatsu A (2013) Effects of elevated seawater $\mathrm{CO}_{2}$ on feed intake, oxygen consumption and morphology of Aristotle's lantern in the sea urchin Anthocidaris crassispina. J Mar Sci Technol 21:192-200

Yeruham E, Abelson A, Rilov G, Ben Ezra D, Shpigel M (2019) Energy budget of cultured Paracentrotus lividus under different temperatures. Aquaculture 501:7-13

Zapata-Vivenes E, Aparicio G (2019) Antioxidant defenses in the coelomic fluid of Echinometra lucunter (Linnaeus, 1758) stimulated with bacterial inoculums. Rev Mar Cost 11:27-42

Zhao C, Sun P, Wei J, Zhang L, Zhang W, Song J, Chang Y (2016) Larval size and metamorphosis are significantly reduced in second generation of inbred sea urchins Strongylocentrotus intermedius. Aquaculture 452:402-406

Zonta R, Botter M, Cassin D, Bellucci LG, Pini R, Dominik J (2018) Sediment texture and metal contamination in the Venice Lagoon (Italy): a snapshot before the installation of the MOSE system. Estuar Coast Shelf S 205:131-151

Zuo RT, Li M, Ding J, Chang YQ (2018) Higher dietary arachidonic acid levels improved the growth performance, gonad development, nutritional value, and antioxidant enzyme activities of adult sea urchin (Strongylocentrotus intermedius). J Ocean Univ China 17:932-940

Publisher's note Springer Nature remains neutral with regard to jurisdictional claims in published maps and institutional affiliations. 